\title{
KINETICS OF Cs SORPTION TO CLAY MINERALS
}

\author{
G. Lujanienè ${ }^{a}$, K. Mažeika ${ }^{\text {a }}$, J. Šapolaitè ${ }^{\mathrm{a}}$, A. Amulevičius ${ }^{\mathrm{a}}$, and S. Motiejūnas ${ }^{\mathrm{b}}$ \\ a Institute of Physics, Savanoriu 231, LT-02300 Vilnius, Lithuania \\ E-mail: lujaniene@ar.fi.lt \\ ${ }^{\mathrm{b}}$ Vilnius Gediminas Technical University, Saulètekio al. 11, LT-10223, Vilnius, Lithuania
}

Received 4 May 2006

\begin{abstract}
Preliminary data of kinetic sorption experiments are presented. Batch sorption experiments with the aim of estimation of distribution coefficient $\left(K_{\mathrm{d}}\right)$ values were conducted using natural clay minerals from the Šaltiškiai quarry and two sets of solutions with different caesium concentrations $\left(C(\mathrm{Cs})=2.30 \cdot 10^{-10} \mathrm{~mol} / 1\right.$ and $\left.C(\mathrm{Cs})=6.80 \cdot 10^{-5} \mathrm{~mol} / \mathrm{l}\right)$. Kinetic sorption experiments indicated insignificant variation of sorption parameters depending on the chemical composition of groundwater and clay minerals. Speciation studies showed the high content (up to 70\%) of exchangeable caesium in experiments with high caesium concentrations. Results of kinetic tracer experiments and sequential extraction studies revealed differences in sorption mechanisms depending on the Cs concentration. Data obtained from sorption-desorption experiments were used to model sorption process by applying the kinetic 4-box model to describe the cation exchange processes on three sites of clay minerals with distinctly different selectivity. The obtained forward and backward exchange rate constants were used to calculate apparent equilibrium constants, which ranged from 1 to 26 and the highest ones were found for reversible sites.
\end{abstract}

Keywords: Cs, distribution coefficients $\left(K_{\mathrm{d}}\right)$, apparent equilibrium constants $\left(K_{\mathrm{ap}}\right)$, clay minerals, radioactive waste

PACS: $28.41 . \mathrm{Kw}$, 82.33.-z, 82.80.Ej, 82.80.Jp

\section{Introduction}

The development of nuclear energy resulted in accumulation of radioactive waste of different activity in various countries, including Lithuania. The isolation of such waste for a long period of time requires the reliable engineered and natural barrier systems where migration of radionuclides should be retarded through different physical and chemical processes. An understanding of geochemical processes affecting the contaminant transport is necessary for assessment of migration of radioactive contaminants in the repository environment. One of the most important issues of this is sorption to clay minerals.

The retardation and engineering extraction of caesium are difficult problems. For sorbing the radionuclides such as Cs, a long time is required to reach steady-state conditions, and its sorption-desorption behaviour in clay minerals is complicated $[1,2]$. The formation of organic and inorganic complexes has negligible effect on caesium speciation and the dominant aqueous species in groundwater is the uncomplexed $\mathrm{Cs}^{+}$ion. It is now generally recognized that $\mathrm{Cs}^{+}$is strongly and selectively sorbed by the phyllosilicate fraction of soils, sediments, and suspended particles, and this selective adsorption of $\mathrm{Cs}$ by mica-like minerals, such as illite $\left\{\left(\mathrm{K}, \mathrm{H}_{3} \mathrm{O}\right)(\mathrm{Al}, \mathrm{Mg}, \mathrm{Fe})_{2}(\mathrm{Si}, \mathrm{Al})_{4} \mathrm{O}_{10}\right.$ $\left.\left[(\mathrm{OH})_{2}, \mathrm{H}_{2} \mathrm{O}\right]\right\}$, can considerably reduce the toxic caesium effect in the natural environment [3]. Recently a few studies have indicated that even highly contaminated organic soils, such as peats, contain trace amounts of illite, which should be sufficient to immobilize the trace amounts of Cs present even in very contaminated soils. It has also been found that the humic substances decrease the adsorption of Cs on clays $[4,5]$. Along with humic substances, the polysaccharides and proteins are the most important organic macromolecules in soils, where they can affect various adsorption sites in different ways, by preventing the clay layer collapse at frayed edge sites, and they can inhibit Cs sorption to clay minerals by modifying the properties of regular exchange sites [6]. The major sorbents are found to be the layer-type silicates that bind Cs either through electrostatic associations of hydrated Cs with anionic surfaces within the basalt plane and dissociated edge hydroxyl groups forming outer-sphere complexes or through electronic bonding at the frayed edge sites (FES), external basalt sites, or within the interlayer forming inner-sphere complexes [7]. The high affinity FES are supposed to constitute only a small 
proportion $\left(\sim 10^{-8} \mathrm{~mol} / \mathrm{kg}\right)$ of the total ones [8]. Caesium adsorption by layer-type silicates has been often described as a cation exchange process on two or more sites with distinctly different selectivity [9-11].

The main $\mathrm{Cs}^{+}$exchange reactions in the multicomponent system are expected to be as follows:

$$
\begin{gathered}
\equiv \mathrm{X}-\mathrm{Na}+\mathrm{Cs}^{+}=\equiv \mathrm{X}-\mathrm{Cs}+\mathrm{Na}^{+}, \\
\equiv \mathrm{X}-\mathrm{K}+\mathrm{Cs}^{+}=\equiv \mathrm{X}-\mathrm{Cs}+\mathrm{K}^{+}, \\
\equiv \mathrm{X}-\frac{1}{2} \mathrm{Ca}+\mathrm{Cs}^{+}=\equiv \mathrm{X}-\mathrm{Cs}+\frac{1}{2} \mathrm{Ca}^{2+},
\end{gathered}
$$

where $\equiv \mathrm{X}$ denotes surface sites on the clay minerals.

The cation exchange of $\mathrm{Cs}^{+}$to layer silicates and soils is usually represented by a mass action equation of the following form $[12,13]$ :

$$
\mathrm{Cs}_{(\mathrm{aq})}^{+}+\frac{1}{u} \mathrm{AX}(i)_{u}=\operatorname{CsX}(i)+\frac{1}{u} \mathrm{~A}_{(\mathrm{aq})}^{u+},
$$

where $u$ is the valence of ionic species $\mathrm{A}, \mathrm{AX}(i)_{u}$ and $\operatorname{CsX}(i)$ are the exchanger phase species of $\mathrm{A}^{u+}$ and $\mathrm{Cs}^{+}$, and $\mathrm{Cs}_{(\mathrm{aq})}^{+}$and $\mathrm{A}_{(\mathrm{aq})}^{u+}$ are aqueous species. The Cs distribution coefficient $K_{\mathrm{d}}$ is defined as

$$
K_{\mathrm{d}}=\frac{[\operatorname{CsX}(i)]}{\left[\mathrm{Cs}_{(\mathrm{aq})}^{+}\right]} .
$$

The rate of exchange of $\mathrm{Cs}^{+}$is

$$
\begin{aligned}
\frac{\mathrm{d}\left[\mathrm{Cs}_{(\mathrm{aq})}^{+}\right]}{\mathrm{d} t}= & -k_{1}\left[\mathrm{Cs}_{(\mathrm{aq})}^{+}\right]\left[\mathrm{AX}(i)_{u}\right]^{1 / u} \\
& +k_{-1}\left[\mathrm{~A}_{(\mathrm{aq})}^{u+}\right]^{1 / u}[\mathrm{CsX}(i)],
\end{aligned}
$$

assuming a first order reaction kinetics, and at a steady state or equilibrium

$$
K_{a p}=\frac{k_{1}}{k_{-1}}=\frac{\left[\mathrm{A}_{(\mathrm{aq})}^{u+}\right]^{1 / u}[\mathrm{CsX}(i)]}{\left[\mathrm{Cs}_{(\mathrm{aq})}^{+}\right]\left[\operatorname{AX}(i)_{u}\right]^{1 / u}},
$$

where $K_{a p}$ is the apparent equilibrium constant, $k_{1}$ and $k_{-1}$ are forward and backward reaction rate constants, respectively, $\mathrm{Cs}_{(\mathrm{aq})}^{+}$is the concentration of caesium in the aqueous phase $(\mathrm{mol} / \mathrm{ml})$, and $\operatorname{CsX}(i)$ is the concentration of adsorbed caesium on the exchange site $i$ $(\mathrm{mol} / \mathrm{g})$.

The aim of this study was to determine the caesium sorption parameters to clay minerals and to investigate the sorption mechanism under different conditions.

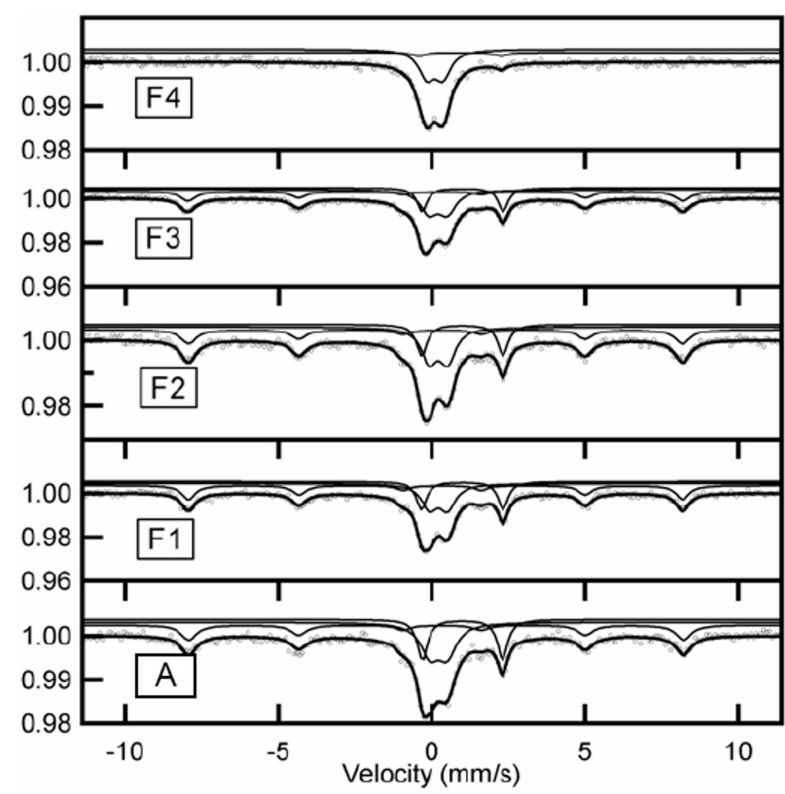

Fig. 1. Room-temperature Mössbauer spectra of the Šaltiškiai clay (sample No. 6): the initial $A$ and after four steps of sequential extraction of iron minerals, $F 1$ (exchangeable and bound to carbonates), F2 (reducible), F3 (bound to organic matter), F4 (aqua regia).

\section{Methods}

Samples of Triassic clay from a site mined for industrial exploitation known as the Šaltiškiai (North Lithuania) quarry were taken for laboratory investigations. X-ray diffraction analyses indicated the presence of about $14 \%$ of montmorillonite in the Triassic clay. The analysis of $<1 \mu \mathrm{m}$ size particles showed the high content of smectite group minerals (from 56 to $71 \%$ ), illite (about 20\%), and chlorite minerals (from 1 to 9\%) in the fraction of smaller than $1 \mu \mathrm{m}$ particles of the Šaltiškiai clay. The chemical composition of the Šaltiškiai clay was estimated as follows: $\mathrm{SiO}_{2}$ made $45.51 \%, \mathrm{Al}_{2} \mathrm{O}_{3} 13.50 \%, \mathrm{Fe}_{2} \mathrm{O}_{3}$ $5.17 \%, \mathrm{MgO} 3.00 \%, \mathrm{CaO} 12.88 \%, \mathrm{Na}_{2} \mathrm{O} 0.28 \%, \mathrm{~K}_{2} \mathrm{O}$ $5.02 \%, \mathrm{TiO}_{2} 0.43 \%$, total $\mathrm{S} 0.16 \%$, the loss on ignition was $13.96 \%$ [14]. The grain size composition of the Triassic clay is characterized by microaggregates of clay particles which are cemented by limonite $\mathrm{FeO}(\mathrm{OH}) \cdot \mathrm{nH}_{2} \mathrm{O}$. The mixture of iron oxide minerals is characteristic of limonite. The presence of $\mathrm{Fe}^{2+}$, lepidocrocite $(\gamma$-FeOOH$)$, siderite $\mathrm{FeCO}_{3}, \mathrm{Fe}$ hydroxides $\left(\mathrm{Fe}(\mathrm{OH})_{3}\right)$, ferrihydrite $\left(\mathrm{Fe}(\mathrm{OH})_{3} \cdot \mathrm{nH}_{2} \mathrm{O}\right)$, hematite $\left(\alpha-\mathrm{Fe}_{2} \mathrm{O}_{3}\right)$, maghemite $\left(\gamma-\mathrm{Fe}_{2} \mathrm{O}_{3}\right)$, goethite $(\alpha-\mathrm{FeOOH})$, and the trace amount of $\varepsilon-\mathrm{Fe}_{2} \mathrm{O}_{3}$ mineral which is rare intermediate between maghemite and hematite were determined by Mössbauer spectrometry in the Šaltiškiai clay [15]. 
The Mössbauer spectra were measured at room temperature using a constant acceleration method in transmission geometry. For the Mössbauer studies, the ${ }^{57} \mathrm{Co}(\mathrm{Rh})$ source was used. The thickness of samples was approximately $100 \mathrm{mg} / \mathrm{cm}^{3}$ of clay. Isomer shifts are given relative to $\alpha$-Fe.

Two samples from the Šaltiškiai quarry were selected for sorption experiments. In samples No. 6 and 7 a different amount of iron oxides and carbonates was determined. Data of Mössbauer spectra of the initial sample No. 6 and after four steps of sequential extraction are presented in Fig. 1. Significant changes in Mössbauer spectra were observed after the step F4 (aqua regia) and after extraction using citrate-bicarbonate-ditionite (CBD). In both cases hematite $\left(\alpha-\mathrm{Fe}_{2} \mathrm{O}_{3}\right)$ was removed, and the sextet associated with it was not observed. In sample No. 7 only a trace amount of iron oxides was found, while a large amount of $\mathrm{CaCO}_{3}$ was determined using X-ray diffraction and atomic absorption spectrometry (AAS) in combination with sequential extraction.

Natural groundwater $(\mathrm{GW})$ and synthetic rainwater (SRW) were used in experiments. The chemical composition of GW and SRW samples is presented in Table 1. The composition of rainwater was estimated taking into account the long-term studies performed in Lithuania [16].

The laboratory batch method was used for the determination of $K_{\mathrm{d}}$ values. The protocol of the standard method used at the Pacific Northwest National Laboratory (USA) for measuring laboratory batch $K_{\mathrm{d}}$ values was applied [17]. Two sets of solutions were prepared for batch experiments. The tests were performed under atmospheric conditions at $25^{\circ} \mathrm{C}$. The sample was disaggregated by an ultrasonic method. The total concentrations of caesium in solutions were $2.30 \cdot 10^{-10} \mathrm{~mol} / 1$ and $6.80 \cdot 10^{-5} \mathrm{~mol} / 1$ (the solutions were labelled by ${ }^{134} \mathrm{Cs}$ ). The sorption of caesium on centrifuge bottle walls was detected to be less than $2 \%$. ${ }^{134} \mathrm{Cs}$ activities were measured with an intrinsic germanium detector (resolution $1.9 \mathrm{keV} / 1.33 \mathrm{MeV}$ and the relative efficiency $42 \%$ ). Duration of measurement varied according to sample activities. An efficiency calibration of the system was performed using calibration sources (prepared from a solution supplied by Amersham, UK) of different densities and geometry that were close to measured samples. Accuracy and precision of analysis were tested in intercomparison runs, organized by the Ris $\varnothing$ National Laboratory, Denmark. The uncertainty of ${ }^{134} \mathrm{Cs}$ measurements by gamma spectrometry was $\leq 3 \%$.

The association of sorbed Cs in the studied geological material was determined using the sequential extraction procedure [18,19]. Exchangeable and carbonate bound $\mathrm{Cs}$ was extracted using $1 \mathrm{~mol} / 1$ $\mathrm{NH}_{4} \mathrm{C}_{2} \mathrm{H}_{3} \mathrm{O}_{2}, \mathrm{pH} 5, \mathrm{CH}_{3} \mathrm{COOH}$ extracting agent.

\section{Results and discussion}

Data of sorption experiments using the clay sample No. 6 and groundwater samples GW4 and GW6 (data: C6, GW4 and C6, GW6) as well as the clay sample No. 7 and groundwater samples GW4 and GW6 (data: C7, GW4 and C7, GW6) are presented in Fig. 2. Very fast adsorption of Cs to clay minerals was observed in all four cases with residence time of Cs in the aqueous phase of about one day. Cs $K_{\mathrm{d}}$ values as functions of time are presented in Fig. 3. The determined $K_{\mathrm{d}}$ values ranged from 80 to $470 \mathrm{ml} / \mathrm{g}$. Insignificantly higher values were found for clay No. 6 . Higher Cs $K_{\mathrm{d}}$ values were expected in experiments using the groundwater sample GW6 with lower concentrations of major ions (Table 1). However, even slightly higher $K_{\mathrm{d}}$ values were observed in experiments with the clay No. 6 and the groundwater GW4 (data: C6, GW4, Fig. 3). It can be explained taking into account the different adsorption selectivity of Cs in a multicomponent $\mathrm{Cs}^{+}-\mathrm{Ca}^{2+}-\mathrm{Na}^{+}-\mathrm{K}^{+}$system. The changes in chemical composition of groundwater are mainly related to an increase in concentrations of $\mathrm{Ca}^{2+}$ and $\mathrm{Na}^{+}$. The concentration of $\mathrm{K}^{+}$in both samples was found to be almost the same, whereas the selectivity coefficients of Cs for mentioned ions can differ more than 10 times. The highest coefficients were determined for $\mathrm{Cs}^{+}-\mathrm{Ca}^{2+}$ and the lowest for $\mathrm{Cs}^{+}-\mathrm{K}^{+}$exchange. In addition, an increase in selectivity coefficients with

Table 1. Physical parameters and major ion concentrations in groundwater solutions used in sorption experiments.

\begin{tabular}{ccccccccccc}
\hline $\begin{array}{c}\text { Type of } \\
\text { solution }\end{array}$ & $\begin{array}{c}\mathrm{SO}_{4}^{2-}, \\
\mathrm{mg} / 1\end{array}$ & $\begin{array}{c}\mathrm{Cl}^{-}, \\
\mathrm{mg} / \mathrm{l}\end{array}$ & $\begin{array}{c}\mathrm{Na}^{+}, \\
\mathrm{mg} / \mathrm{l}\end{array}$ & $\begin{array}{c}\mathrm{K}^{+}, \\
\mathrm{mg} / 1\end{array}$ & $\begin{array}{c}\mathrm{Ca}^{2+}, \\
\mathrm{mg} / 1\end{array}$ & $\begin{array}{c}\mathrm{Mg}^{2+}, \\
\mathrm{mg} / 1\end{array}$ & $\begin{array}{c}\mathrm{HCO}_{3}^{-} \\
\mathrm{mg} / 1\end{array}$ & $\mathrm{pH}$ & $\begin{array}{c}\mathrm{U}, \\
\mathrm{mV}\end{array}$ & $\begin{array}{c}\chi, \\
\mathrm{mS} / \mathrm{cm}\end{array}$ \\
\hline $\mathrm{GW} 4$ & 40.3 & 22.4 & 10.4 & 1.9 & 139 & 39.7 & 517 & 7.16 & -71.7 & 0.863 \\
$\mathrm{GW6}$ & 22.8 & 5.2 & 5.2 & 1.6 & 89.6 & 24.9 & 367 & 7.47 & -69.8 & 0.535 \\
$\mathrm{SRW}$ & 1.22 & 0.75 & 0.58 & 0.14 & 0.42 & - & 90.0 & 4.89 & 108.5 & 0.23 \\
\hline
\end{tabular}




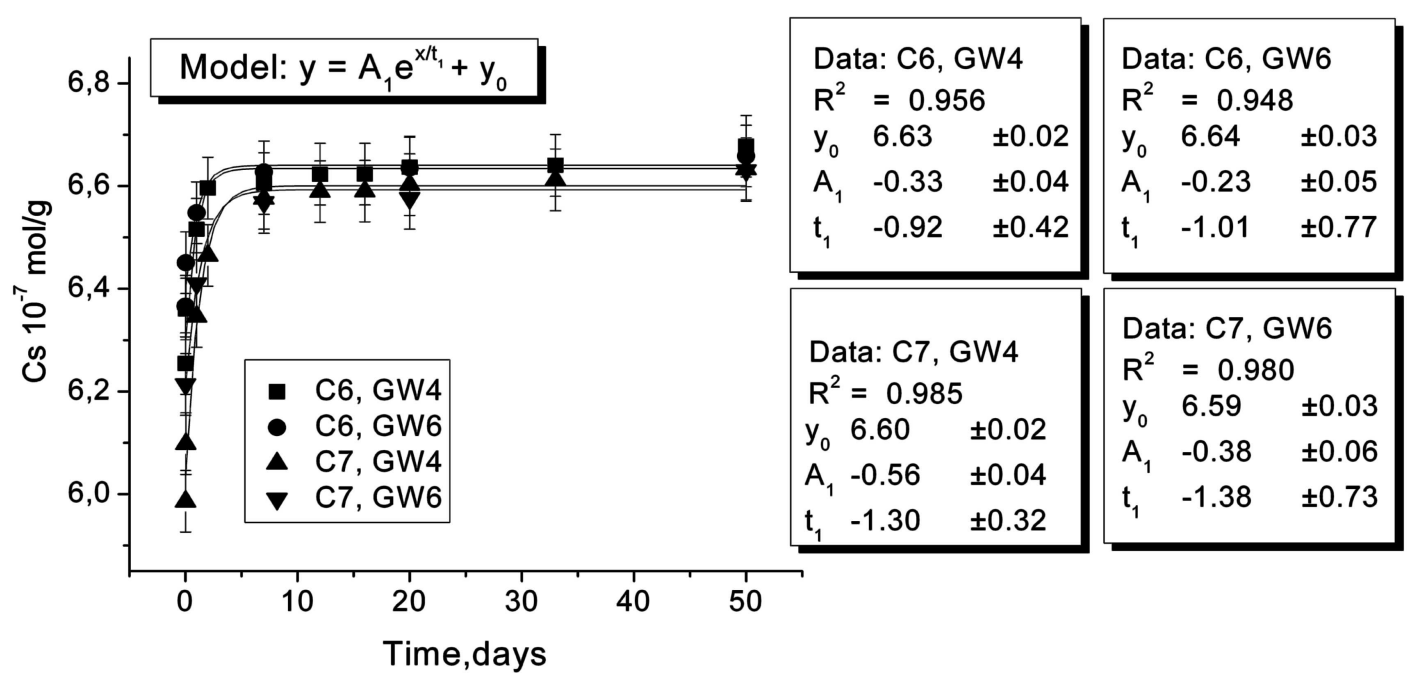

Fig. 2. $\mathrm{Cs}^{+}$adsorption on clay minerals (Šaltiškiai clay samples No. 6 and 7, groundwater samples No. 4 and 6 ) as a function of time $\left(C(\mathrm{Cs})=6.80 \cdot 10^{-5} \mathrm{~mol} / \mathrm{l}\right)$.

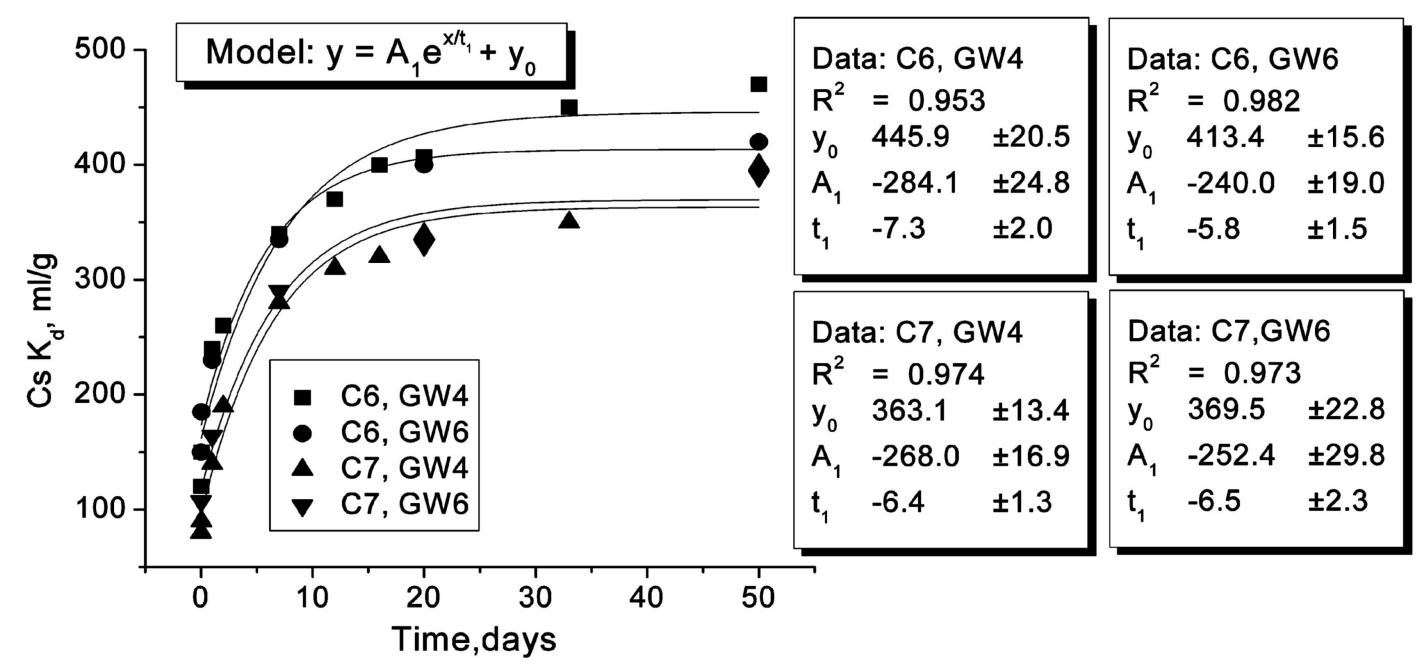

Fig. 3. Cs $K_{\mathrm{d}}$ values as a function of time (Šaltiškiai clay samples No. 6 and 7, groundwater samples No. 4 and $\left.6, C(\mathrm{Cs})=6.80 \cdot 10^{-5} \mathrm{~mol} / \mathrm{l}\right)$.

increasing the electrolyte concentration indicated that the $\mathrm{Cs}$ exchange processes were nonideal for $\mathrm{Cs}^{+}-\mathrm{Na}^{+}$ and $\mathrm{Cs}^{+}-\mathrm{K}^{+}$exchange systems [10]. Sequential extraction studies showed rather similar Cs partitioning to various geochemical phases (Fig. 4). Cs was mainly found in the exchangeable and bound to carbonate fraction of clay minerals (up to 70\%) and this large amount can be considered as reversibly sorbed caesium ( $F 2$, Fig. 4). It should be noted that only insignificant variations were observed on the time scale of the study from $10 \mathrm{~min}$ to 50 days. Thus, sorption experiments and data obtained from sequential extraction studies indicated fast sorption processes, high reversibility, and almost full equilibrium in the system after 50 days of sorption experiments with the high caesium concentration $\left(C(\mathrm{Cs})=6.80 \cdot 10^{-5} \mathrm{~mol} / \mathrm{l}\right)$. Contrary to these findings the slow sorption process and large variations in the Cs sorption reversibility are characteristic of Cs behaviour in the natural environment $[20,21]$. However, $K_{\mathrm{d}}$ concept, usually used as a simplified approach to the complex sorption-desorption processes, is by definition restricted to instantaneous equilibrium and full reversibility.

In sorption experiments performed using the Šaltiškiai clay and using groundwater with low caesium concentrations $\left(C(\mathrm{Cs})=2.30 \cdot 10^{-10} \mathrm{~mol} / \mathrm{l}\right)$, which were close to that usually found in the natural environment, Cs $K_{\mathrm{d}}$ values ranged from 7000 to $10000 \mathrm{ml} / \mathrm{g}$ [22]. The lowest Cs $K_{\mathrm{d}}$ values were found in experiments with synthetic rainwater (Table 1), however, an increase in Cs $K_{\mathrm{d}}$ values was observed during 45 days (Fig. 5). Sequential extraction studies indicated that variations of caesium concentrations in the groundwater affected the partitioning of Cs to clay 
C6, GW4

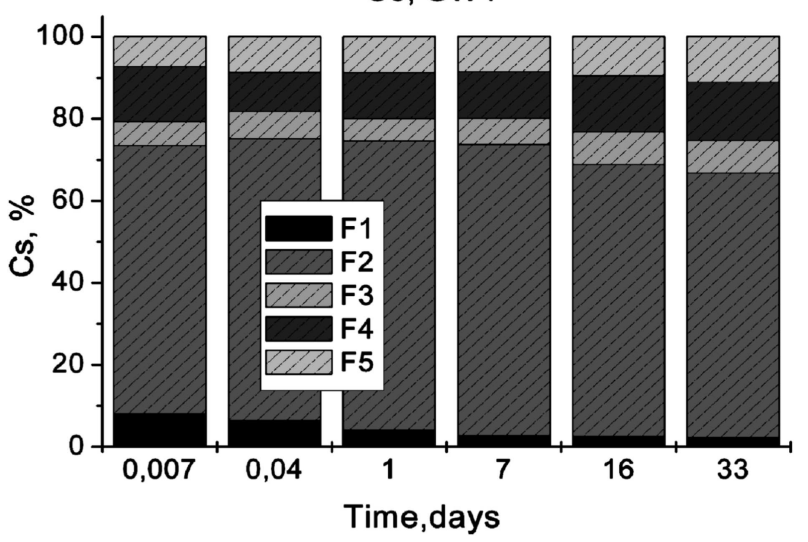

C7, GW4

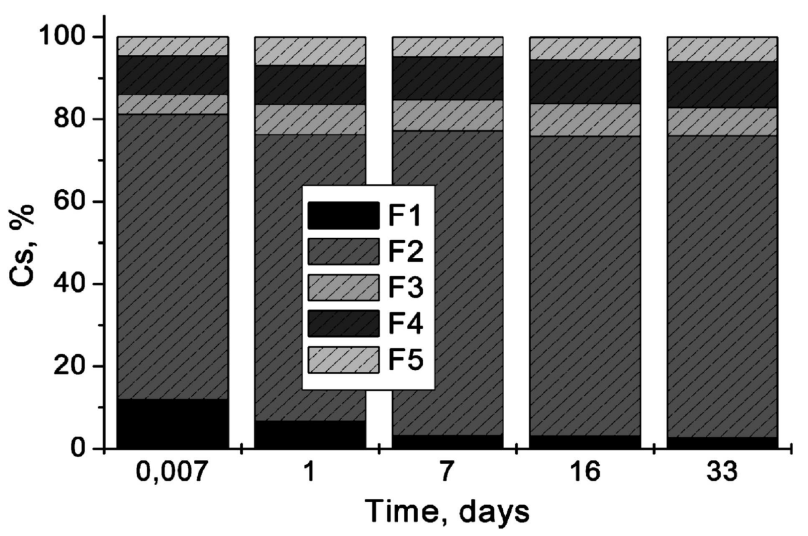

C6, GW6

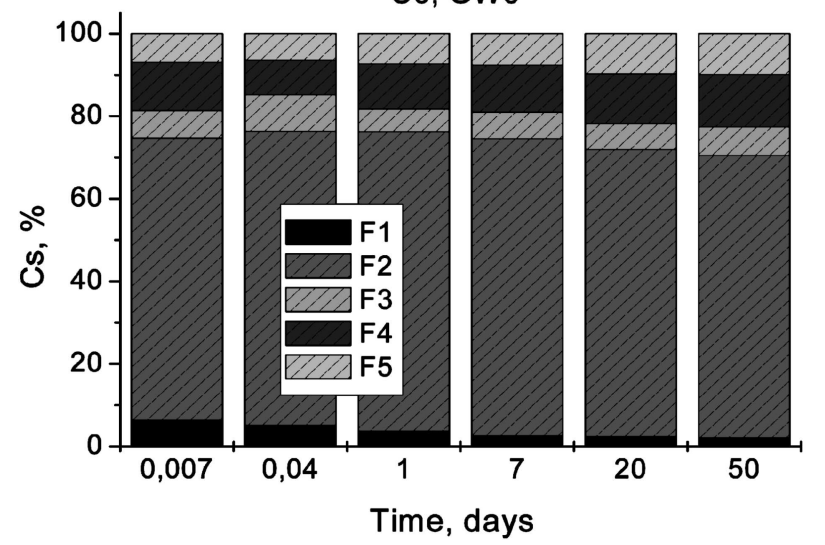

C7, GW6

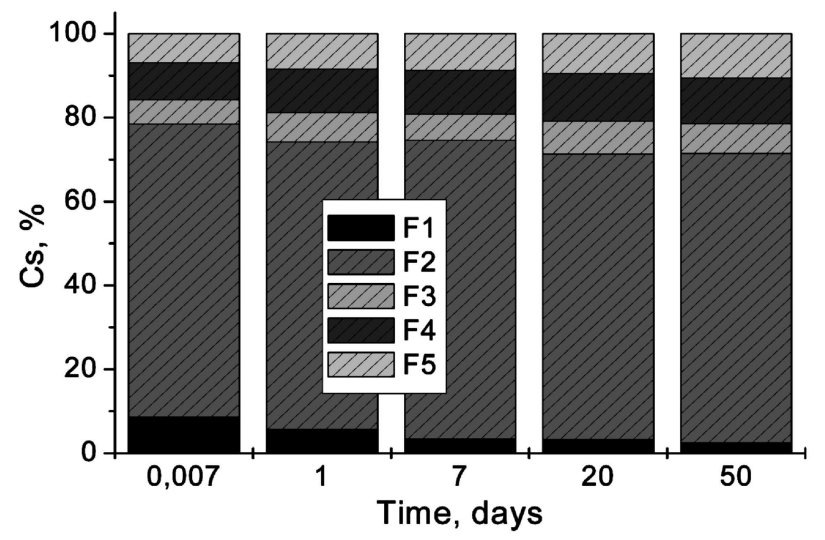

Fig. 4. Fraction distribution of Cs (Šaltiškiai clay samples No. 6 and 7, groundwater samples No. 4 and 6 ) as a function of time. $F 1$ is in groundwater, $F 2$ is exchangeable and bound to carbonates, $F 3$ is reducible, $F 4$ is bound to organic matter, $F 5$ is residual $(C(\mathrm{Cs})=$ $\left.6.80 \cdot 10^{-5} \mathrm{~mol} / \mathrm{l}\right)$.

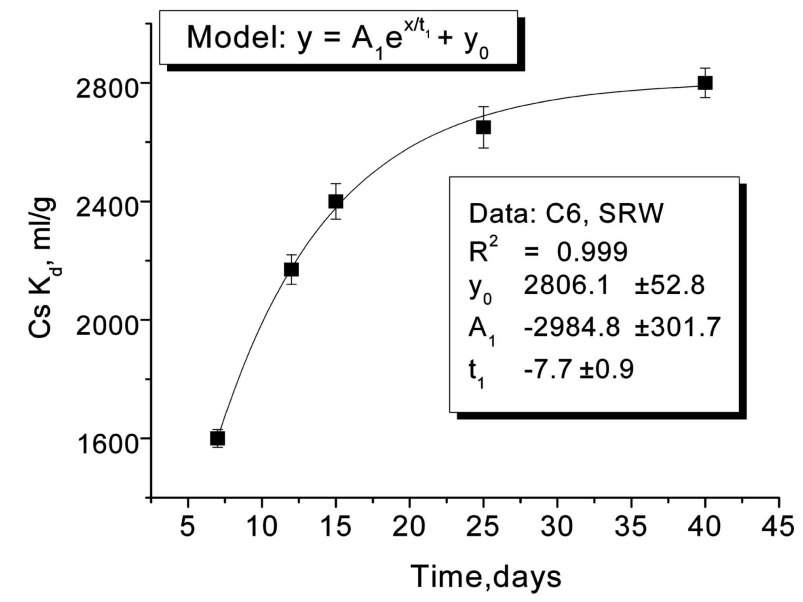

Fig. 5. Cs $K_{\mathrm{d}}$ values as a function of time (Šaltiškiai clay sample No. 6 and synthetic rainwater $\left.(\mathrm{SRW}), C(\mathrm{Cs})=2.30 \cdot 10^{-10} \mathrm{~mol} / \mathrm{l}\right)$.

[23]. The main differences deal with an amount of caesium sorbed to sites from which it can be easily desorbed (exchangeable fraction) and to sites from which it cannot be desorbed (acid soluble and residual fraction). Average values of $\mathrm{Cs}$ in both fractions in exper-

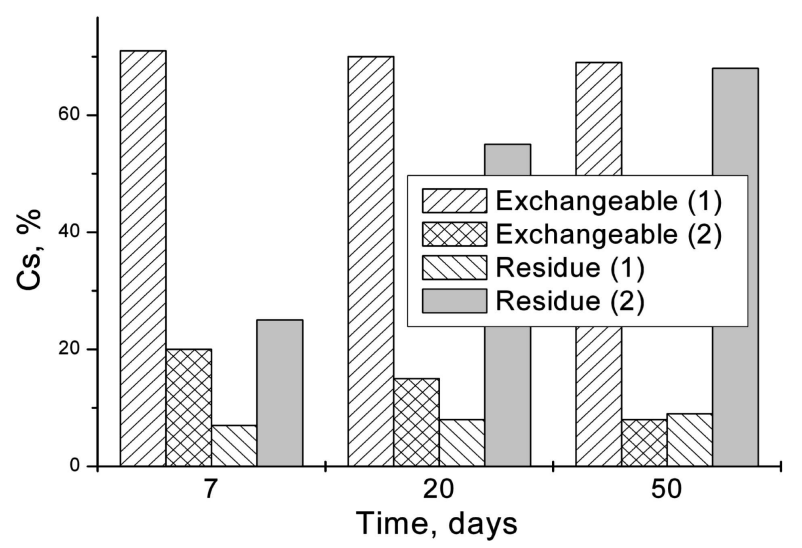

Fig. 6. Fraction distribution of $\mathrm{Cs}$ in Šaltiškiai clay (average data) as a function of time (exchangeable (1) and residue (1) with $C(\mathrm{Cs})=6.80 \cdot 10^{-5} \mathrm{~mol} / 1$ and exchangeable (2) and residue (2) with $\left.C(\mathrm{Cs})=2.30 \cdot 10^{-10} \mathrm{~mol} / \mathrm{l}\right)$.

iments with low and high concentrations are presented in Fig. 6. The decrease in the Cs amount in exchangeable fraction (exchangeable (2)) and the decrease in the Cs amount in residual fraction (residue (2)) were determined in experiments with low Cs concentrations, 


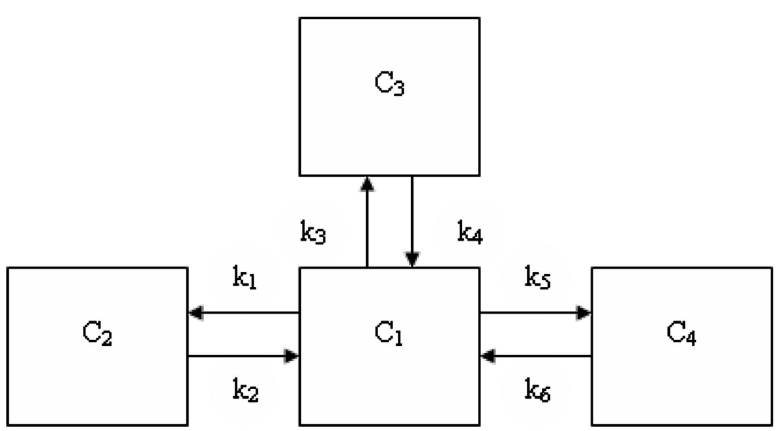

Fig. 7. Schematic representation of the kinetic 4-box model.

while no changes (exchangeable (1) and residue (1)) were observed in experiments with the high concentrations. It can be explained by sorption of caesium to sites of different affinity. Generally, FES of micas and illites act as the high affinity sites, while basal and interlamellar regions of expansible layer silicates, such as smectites, act as lower selectivity sites. The studied clay consists mainly of smectite type minerals with a small amount of illite. Thus, the selective sorption sites of FES were available for Cs at illite and were capable of binding $\mathrm{Cs}$ at trace concentrations. In experiments with high Cs concentrations, almost all caesium was sorbed to smectite on sites of lower selectivity.

Data obtained from sorption-desorption experiments were used to model the sorption process. The kinetic 4-box model was used (Fig. 7) to describe the cation exchange processes on three sites of different selectivity. The sorption sites can be defined on the basis of sequential extraction data. The Cs sorbed to the first type of sorption sites (box 2, concentration of radionuclide $C_{2}$ ) can be defined as reversibly sorbed Cs to clay, the amount of which was determined as the exchangeable fraction of the first step of sequential extraction (F2, Fig. 4). The Cs sorbed to the second type of sorption sites (box 3, concentration of radionuclide $C_{3}$ ) can be characterized as slowly reversible Cs, the release of which into solution is strongly dependent on oxidation-reduction processes in the system. The slowly reversible Cs was determined as a Cs amount extracted during the sequential extraction analyses (the $F 3$ and $F 4$ fractions which usually contain radionuclides bound to oxides and organic matter, respectively) (Fig. 4). The Cs sorbed to the third type of sorption sites (box 4, concentration of radionuclide $C_{4}$ ) can be described as partly or / and fully irreversibly sorbed Cs, the amount of which was estimated as the residual fraction of the sequential extraction (F5, Fig. 4). The definition of sorption sites is quite relative because of heterogeneous origin of the natural geological material containing the various sorption sites of different selec- tivity. The sorption sites were defined on the basis of desorption capabilities and on the general knowledge about sorption of caesium to clay minerals. The kinetic equations of the 4-box model are:

$$
\begin{aligned}
& \frac{\mathrm{d} C_{2}}{\mathrm{~d} t}=k_{1} C_{1}-k_{2} C_{2}, \\
& \frac{\mathrm{d} C_{3}}{\mathrm{~d} t}=k_{3} C_{1}-k_{4} C_{3}, \\
& \frac{\mathrm{d} C_{4}}{\mathrm{~d} t}=k_{5} C_{1}-k_{6} C_{4},
\end{aligned}
$$$$
\frac{\mathrm{d} C_{1}}{\mathrm{~d} t}=-k_{1} C_{1}+k_{2} C_{2}-k_{3} C_{1}
$$$$
+k_{4} C_{3}-k_{5} C_{1}+k_{6} C_{4},
$$

where $C_{1}$ is the concentration of the radionuclide in solution, $C_{2}$ is the concentration of reversibly sorbed Cs, $C_{3}$ is the concentration of slowly reversible Cs, $C_{4}$ is the concentration of irreversibly sorbed Cs, and $k_{1}-$ $k_{6}$ are forward and backward exchange rate constants.

We tried to describe complicated Cs sorption processes on the natural clay minerals that include sorption on reversible sorption sites and frayed edge sites as well as sorption sites containing iron and organic matter coatings (slowly reversible sites). The kinetic equations of the 4-box model were integrated and fitted to the experimental results obtained from the kinetic tracer experiment using the least-squares procedure. The set of kinetic equations has been integrated applying the Bader and Deuflhard method [24], which allows obtaining high accuracy even for stiff integral equations. The obtained forward and backward exchange rate constants have been used to calculate apparent equilibrium constants which are presented in Table 2. The apparent equilibrium constants range from 1 to 26 and the highest ones are found for reversible sites. A high Cs content in the reversible fraction indicates the possible radionuclide release into surrounding solution and, hence, the amount of caesium available for transport. Thus, the knowledge about the apparent equilibrium constants is important since the $K_{\mathrm{d}}$ values are very complicated functions of many parameters.

\section{Conclusions}

Very fast adsorption of Cs to clay minerals was observed under studied conditions with residence time of 
Table 2. Apparent equilibrium constants for Cs sorbed to reversible (1), slowly reversible (2), and irreversible (3) sites.

\begin{tabular}{ccccc}
\hline Site & Clay No. 6, GW4 & Clay No. 6, GW6 & Clay No. 7, GW4 & Clay No. 7, GW6 \\
\hline 1 & 18.6 & 26.4 & 18.2 & 23.4 \\
2 & 5.3 & 6.7 & 4.5 & 6.1 \\
3 & 2.6 & 3.0 & 1.3 & 3.1 \\
\hline
\end{tabular}

Cs of about one day in the aqueous phase. The determined $K_{\mathrm{d}}$ values ranged from 80 to $470 \mathrm{ml} / \mathrm{g}$.

The sequential extraction investigation indicated rather similar Cs partitioning to various geochemical phases of both clays in the experiments with different groundwater samples. Cs was mainly found in the exchangeable and bound to carbonate fraction of clay minerals (up to $70 \%$ ).

The estimated apparent equilibrium constants ranged from 1 to 26 and the highest ones were found for reversible sites.

\section{Acknowledgements}

This study was supported by the Radioactive Waste Management Agency and the Lithuanian State Science and Studies Foundation project No. C-19/2003. In addition, we would like to express our gratitude to $\mathrm{Dr}$ D. Valiulis for assistance in the performance of measurements.

\section{References}

[1] T. Kozaki, H. Sato, S. Sato, and H. Ohashi, Diffusion mechanism of caesium in compacted montmorillonite, Engineering Geology 54, 223-230 (1999).

[2] J.L. Krumhansl, P.V. Brady, and H.L. Anderson, Reactive barriers for ${ }^{137} \mathrm{Cs}$ retention, J. Contam. Hydrol. 47, 233-240 (2001).

[3] R.M. Cornell, Adsorption of cesium on minerals: A review, J. Radioanal. Nucl. Chem., Articles 171, 483500 (1993).

[4] A. Rigol, M. Vidal, G. Rauret, C.A. Shand, and M.V. Cheshire, Competition of organic and mineral phases in radiocesium partitioning in organic soils of Scotland and the area near Chernobyl, Environ. Sci. Technol. 32, 663-669 (1998).

[5] A.B. Hird, D.L. Rimmer, and F.R. Livens, Total caesium-fixing potencials of acid organic soils, J. Environ. Radioactivity 26, 103-118 (1995).

[6] C. Dumat, H. Quiquampoix, and S. Stauton, Adsorption of cesium by synthetic clay-organic matter complexes: Effect of the nature of organic polymers, Environ. Sci. Technol. 34, 2985-2989 (2000).

[7] B.C. Bostick, M.A. Vairavamurthy, Karthikeyan, and J. Chorover, Cesium adsorption on clay minerals:
An EXAFS spectroscopic investigation, Environ. Sci. Technol. 36, 2670-2676 (2002).

[8] E. Brouwer, B. Baeyens, A. Maes, and A. Cremers, Cesium and rubidium ion equilibria in illite clay, J. Phys. Chem. 87, 1213-1219 (1983).

[9] M.H. Bradbury and B. Baeyens, A generalised sorption model for the concentration dependent uptake of caesium by argillaceous rocks, J. Contam. Hydrol. 42, 141-163 (2000).

[10] C. Liu, J.M. Zachara, and S.C. Smith, A cation exchange model to describe $\mathrm{Cs}^{+}$sorption at high ionic strength in subsurface sediments at Hanford site, USA, J. Contam. Hydrol. 68, 217-238 (2004).

[11] C. Poinssot, B. Baeyens, and M.H. Bradbury, Experimental and modeling studies of caesium sorption on illite, Geochim. Cosmochim. Acta 63, 3217-3227 (1999).

[12] J.M. Zachara, S.C. Smith, C. Liu, J.P. McKinley, R.J. Serne, and P.L. Gassman, Sorption of $\mathrm{Cs}^{+}$to micaceous subsurface sediments from the Hanford site, USA, Geochim. Cosmochim. Acta 66, 193-211 (2002).

[13] C.I. Steefel, S. Carroll, P. Zhao, and S. Roberts, Cesium migration in Hanford sediment: A multisite cation exchange model based on laboratory transport experiments, J. Contam. Hydrol. 67, 219-246 (2003).

[14] Characterisation of Materials Suitable for Engineering Barriers of Near Surface Repository of Radioactive Waste (Vilnius, Ecofirma, 2004) [in Lithuanian].

[15] G. Lujanienè, J. Šapolaitè, A. Amulevičius, K. Mažeika, and S. Motiejūnas, Retention of cesium, plutonium and americium by engineered and natural barriers, Czech J. Phys. (2006, in press).

[16] Measurement data of the Lithuanian state air monitoring, http://aaa.am.1t/.

[17] K.M. Krupka, D.I. Kaplan, G. Wheland, R.J. Serne, and S.V. Mattigod, Understanding variation in partition coefficients, Kd, values, EPA Report 402-R-99-004A (US Environment Protection Agency, Office of Air and Radiation, Washington, 1999).

[18] A. Sahuquillo, A. Rigol, and G. Rauret, Overview of the use of leaching / extraction tests for risk assessment of trace metals in contaminated soils and sediments, Trends in Anal. Chem. 22, 152-159 (2003).

[19] G. Rauret, J.F. Lopez-Sanchez, A. Sahuquillo, R. Rubio, C. Davidson, A. Ure, and Ph. Quevauviller, Improvement of the BCR threestep sequention extraction procedure prior to the sertification of new sediment and 
soil reference material, J. Environ. Monitor. 1, 57-61 (1999).

[20] D.J. Bunker, J.T. Smith, F.R. Livens, and J. Hilton, Determination of radionuclide exchangeability in freshwater systems, Sci. Technol. 263, 171-183 (2000).

[21] A. de Koning and R.N.J. Comans, Reversibility of radiocaesium sorption on illite, Geochim. Cosmochim. Acta 68, 2815-2823 (2004).

[22] G. Lujanienè, S. Motiejūnas, J. Šapolaite, and Z. Ka- marauskas, $\mathrm{Cs}$ and $\mathrm{Pu}$ migration through engineered and natural barriers, Lithuanian J. Phys. 45, 273-280 (2005).

[23] G. Lujanienè, S. Motiejūnas, and J. Šapolaitè, Sorption of Cs, Pu and Am on clay minerals, J. Radioanal. Nucl. Chem. (2006, in press).

[24] G. Bader and P. Deuflhard, A semi-implicit mid-point rule for stiff systems of ODE, Numerische Mathematik 41, 373-398 (1983).

\title{
Cs GERTIES MOLIO MINERALAIS KINETIKA
}

\author{
G. Lujanienè ${ }^{\mathrm{a}}$, K. Mažeika ${ }^{\mathrm{a}}$, J. Šapolaitè ${ }^{\mathrm{a}}$, A. Amulevičiuss ${ }^{\mathrm{a}}$, S. Motiejūnas ${ }^{\mathrm{b}}$ \\ ${ }^{\text {a }}$ Fizikos institutas, Vilnius, Lietuva \\ ${ }^{\mathrm{b}}$ Vilniaus Gedimino technikos universitetas, Vilnius, Lietuva
}

\section{Santrauka}

Pateikti parengtiniai gerties kinetikos eksperimentiniu tyrimu rezultatai. Naudojant natūralaus molio ėminius iš Šaltiškių karjero (šiaurès Lietuva) ir dviejų skirtingų cezio koncentraciju $(C(\mathrm{Cs})=$ $2,30 \cdot 10^{-10} \mathrm{~mol} / 1$ ir $\left.C(\mathrm{Cs})=6,80 \cdot 10^{-5} \mathrm{~mol} / \mathrm{l}\right)$ tirpalus, buvo eksperimentiškai tirta gertis Cs pasiskirstymo koeficientams $\left(K_{\mathrm{d}}\right)$ ivvertinti. Iš tų tyrimų rezultatų paaiškejjo, kad priklausomai nuo gruntinio vandens ir molio mineralu cheminès sudèties gerties parametrai kinta nežymiai. Eksperimentuojant su didelèmis cezio koncentracijomis, buvo aptiktas didelis (iki 70\%) pakaitinio cezio kiekis.
Kinetikos eksperimentų ir nuoseklios ekstrakcijos tyrimų rezultatai atskleidè gerties mechanizmų skirtumų priklausomybę nuo Cs koncentracijos. Rezultatai, gauti iš gerties-atvirkštinès gerties eksperimentų, buvo naudojami gerties vyksmams modeliuoti, taikant kinetini keturių dèžučiu modelị, atvaizduojantị katijonų mainų vyksmus trijose molio mineralų gerties vietose, kur gerai išreikšti atrankumo skirtumai. Surastos gerties reakciju spartos konstantos buvo naudojamos apskaičiuojant pusiausvyros konstantas, kurios kito nuo 1 iki 26. Didžiausios jų vertès gautos mineralų grį̌̌tamosios gerties vietose. 